\title{
Consumer behavior related to buying wines on the retail market in the City of Niš
}

\section{Zoran Simonović}

Institute of Agricultural Economics, Belgrade, Serbia

Nikola Ćurčić

Institute of Agricultural Economics, Belgrade, Serbia

\begin{abstract}
The subject matter of the paper is research in consumer behavior in connection with the purchase of wines of both domestic and foreign brands on the market of the City of Niš. The paper is structured so as to perceive the issue from several aspects. In the first place, our wish was to determine whether the respondents are regular wine consumers, and which sorts of wine they consume, and how many of them are not wine regular consumers. An effort was made to determine consumer habits via survey research. The examination method that implied personal examination using a questionnaire was applied. The suitable sample included 230 respondents from the territory of the City of Niš. The research was conducted in November 2019.

While processing the data, it was noticed that a larger number of the respondents were regular wine consumers, namely consuming specific brands. The respondents mainly preferred domestic producers' wines. The results obtained can be observed at the level of the strategic marketing of the offering companies. The research study provides an insight in connection with the different aspects of the consumer behavior of those who consume wine, both at the general level and in connection with the choice of brands.
\end{abstract}

\section{Keywords}

consumer behavior, marketing research, brand, wine, Niš

\section{Introduction}

Competition on the domestic wine market is quite pronounced. Struggling to acquire a loyal consumer, in many cases it is not necessary to maintain a fixed lower price for the product; - it is enough to view this problem from the multiple aspects that can be important when selecting a certain wine. In this case, the significance of marketing is dual - in the first place, it reflects the knowledge of the current determinants in the said scientific area, and in the second place, it reflects the significance of conducting the marketing research itself that was carried out via a survey. Wine marketing is a specific field within marketing strategies, having specific particularities. (Martinho, 2021). Wine suits this research idea. When considering consumer behaviour related to wine, product design and especially labeling are a strong decision factor in the buying process, with high relevance to the strategic positioning of the producer. Labels provide relevant product information but also serve for strategic communication by the producer. (Dressler, Paunovic, 2021)

The wine industry in Serbia is a significant sector of economic activity that has the potential to stimulate development in agricultural and rural areas. Increasing the quality of wine in the Republic of Serbia will contribute to the improvement of the country's market position and its domestic and international competitiveness. (Balenović, et al., 2021). 
The subject matter of the paper is research into consumer behavior in connection with buying and consuming wine on the market of Niš. An effort was made in the paper to determine how many respondents participating in the survey buy wine and drank it in their households, whether they buy wines of specific brands, and how many of them do not; whether when selecting wines they prefer white, red or rosé wine.

The research in the wine sale channels shows that big supermarket chains mainly offer a large assortment of imported wines of varying quality and domestic wines of lower and medium quality. Admittedly, there has been a trend of the presence of higher-quality domestic wines recently, which have increasingly been included in the offer. The majority of retail facilities - mainly convenience stores - are insufficiently supplied with wines, and if they are, those are mainly low-quality wines. The most significant high-quality Serbian wine distributors are shops and restaurants. Wine boutiques are owned by some wine producers, and their offer consists of their own wines and sometimes imported wines (Salai, Gašović, \& Čelić, 2013).

The wine world is going through a rapid transformation linked to changes in consumer preferences, consumption habits, climate, new regulations, and the reduction in available economic resources. (Merlino, et al., 2021)

Wine culture is defined as refined and civilized wine consuming not measured by the quantity of the wine consumed, but rather measured by the acquired knowledge of brands and procedures in the fields of viticulture, wine production and hospitality. A combination of food and wine very often makes a meal a unique gastronomic experience, simultaneously respecting the rule that there is no such wine that cannot be combined with a meal, and enjoying good wine is always a ceremonial event for connoisseurs. Food, wine, culture and other elements create new commercial and territorial opportunities for brands (Cristófol, Cruz-Ruiz, \& Zamarreño-Aramendia, 2021). A dominant segment of the population in Serbia consider themselves to be wine consumers, so, although wine is classified into the group of alcoholic drinks, it is often served in many homes in accordance with the tradition and customs, together with brandy and beer (Vlahovic, Potrebić, \& Jeločnik, 2013).

\section{Methodology and data sources}

As sources for writing this paper related to consumer behavior within marketing, the following books are certainly significant: Kotler \& Keller (2006). Marketing Management, and Fahy \& Jobber (2012). Foundations of Marketing.

The inevitable book in the marketing management process is by all means a book by Kotler and Armstrong (2014). Principles of Marketing.

While writing this paper, an effort was made to apply the above-mentioned methodology from the generally known literature to the level of wine sale and consumption. So, special attention was paid in this paper to the aspects of consumer behavior when speaking about wine buying and consumption, the factors of the choice of particular brands, and the consumption of particular sorts of wine.

The methods used in the paper best reflect the character of the analysis given in the title of the paper. The quantitative methods of economic analysis are predominant in wine sale research. In the first place, those are various statistical data and literature sources related to consumer behavior. While conducting the research, the analysis of the content of the secondary data sources was also carried out. The secondary data sources (information) are, first of all, related to the statistical research in consumer behavior. Internet-based information, which is abundant and significant, was also used.

The contribution of the paper is reflected in the original reviews and analysis related to consumer behavior when speaking about buying and consuming wine, the factors of the choice of particular brands and the consumption of particular sorts of wine.

An effort was made in the paper to indicate the fact that wine sale, and, simultaneously, wine consumption, are substantial on the territory of Niš. As can be seen in the paper, the result of this research study is an attempt to gain knowledge of the real condition of wine consumption, which may have an influence on the potential model that may result in initiating business activities, primarily in small family-owned wineries.

A special contribution has been achieved in the part of the research paper that is processed based upon the conducted survey.

An effort was made in the paper to provide an insight into the current state of the matters in connection with wine consumption on the territory of Niš - namely, if and to what extent 
wine is consumed, which brands are the most present, which wines are most frequently consumed (white or red wines), whether consumers prefer domestic or foreign wines, and what they think of the price of domestic and what they think of the price of foreign wines.

\section{Research}

\subsection{Sample}

The research study was carried out on the territory of the City of Niš. The encompassed population were those aged from 18 to 75 . The main condition was that a person or a respondent bought wine for the household and/or that he/she decided whether to buy it or not. A convenient sample was used. The research study was carried out in October and November 2019. A total of 230 respondents were included in the survey, simultaneously endeavoring to make their age group distribution match the distribution at the level of the whole population of the city.

The sample includes $39.7 \%$ of men and $60.3 \%$ of women. Of the total number of the respondents, a total of $68.2 \%$ are employed, $14.6 \%$ are unemployed, $6.3 \%$ are students, and $10.9 \%$ are retired persons. Simultaneously, a total of $74.6 \%$ of the respondents are married, whereas a total of $25.4 \%$ are not. The average age of the respondents is 46.1 , the average household size is 3.34 members, and the average number of years of education is 12.11 .

\subsection{Questionnaire}

For the needs of this research study, an original questionnaire was developed by applying factor analysis. Apart from the said factor analysis, more precisely, apart from the analysis of the factors in the development of the questionnaire, the rational method based upon the application of the knowledge of the experts in the fields of enology and marketing was also used. Namely, the initial questionnaire was built into the first step by engaging experts from the mentioned fields, simultaneously taking care of the fundamental bases on which classical test theory is built. Based on their knowledge and experience, they made a proposal for the initial questionnaire consisting of a total of the 60 questions that encompassed all the aspects pertaining to the behavior, i.e. the decision-making process, of wine consumers on the territory of the City of Niš. While creating the initial questionnaire, they particularly took care of the internal consistency of the questions, the problems related to the semantics, the avoidance of double negations in the formulation of the questions and so forth. In the second step, the initial questionnaire was validated by applying factor analysis. To be more precise, the principal components analysis was carried out for this purpose.

For the needs of the validation of the initial questionnaire, a total of 500 respondents were included in the survey, simultaneously taking care of the presence of the sample regarding the respondents' sex, education, labor engagement and purchasing power. The internal consistency of the questionnaire was measured by using the Cronbach alpha coefficient (Hinkin, 1998, pp. 104 $-121)$ :

$\alpha=\frac{\left(N^{2} M(\operatorname{Cov})\right)}{\left(\sum s^{2}+\sum \operatorname{Cov}\right)}$

where:

$\alpha$ - Cronbach alpha coefficient

$N$ - The number of the variables/questions,

$M$ - The number of the variables/questions reduced by 1

$S^{2}$-Variance,

Cov - Covariance

The value of this coefficient was 0.812 , which is indicative of the fact that there is consistency between the questions. Apart from this indicator of the internal consistency between the questions, the validation of the questionnaire was carried out by also using the principal components analysis. Given the fact that the first step in the application of this type of factor analysis implies the examination of the adequacy of the sample size, the KMO test was applied. Numerous authors point out the fact that it is only enough to ensure a total of 10 to 15 respondents per question for a sample to be adequate for the validation of a questionnaire (Petrović, 2013, p. 579) although there are also those who highlight the fact that it is only enough for the value of the KMO test to exceed 0.6 (Field, 2009, p. 8). The first pool of authors base their attitude upon the belief that it is a sufficient size of a sample in the existence of an inverse relationship between the sample size and the probability that the correlation coefficients between the questions from the questionnaire will differ from the correlation coefficients between the questions in other samples (Field, 2009, p. 8). The value of this test was 0.792 .

Given the fact that the principal components analysis implies that data should be intervals since 
the same is based upon the assumption that said data included in a questionnaire are normally distributed, a further analysis was carried out based upon the assumption that the data were normally distributed and treated as intervals in spite of the fact that those were ordinal data.

In order to identify the key factors, i.e. a reduction in the number of the questions from the initial questionnaire, principal components analysis was applied, noting that the condition stipulating that a factor should have the eigenvalue greater than 1 was used as the factor extraction criterion. Table 1 accounts for the results of the application of the analysis.

Table 1 The extracted factors

\begin{tabular}{|c|c|c|c|c|c|c|c|}
\hline \multirow[t]{2}{*}{ Factors } & \multicolumn{3}{|c|}{ The Initial Values of Factors } & \multicolumn{3}{|c|}{ 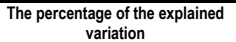 } & \multirow{2}{*}{ 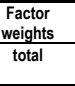 } \\
\hline & total & $\begin{array}{l}\% \text { of the } \\
\text { variation }\end{array}$ & $\begin{array}{c}\text { Cum } \\
\%\end{array}$ & total & $\begin{array}{l}\text { \% of the } \\
\text { variation }\end{array}$ & $\underset{\%}{\mathrm{Cum}}$ & \\
\hline 1 & 5.274 & 18.999 & 18.999 & 5.274 & 18.999 & 18.999 & 4.971 \\
\hline 2 & 3.236 & 14.738 & 33.737 & 3.236 & 14.738 & 33.737 & 3.654 \\
\hline 3 & 2.387 & 11.977 & 45.714 & 2.387 & 11.977 & 45.714 & 3.144 \\
\hline 4 & 1.881 & 11.133 & 56.847 & 1.881 & & 56.847 & \\
\hline 5 & 1.482 & 10.468 & 67.315 & 1.482 & 10.468 & 67.315 & $\frac{3.475}{3.75}$ \\
\hline 6 & 1.155 & 9.597 & 76.912 & 1.155 & 9.597 & 76.912 & 2.985 \\
\hline 7 & 1.131 & 3.984 & 80.896 & 1.131 & 3.984 & 80.896 & 3.3 \\
\hline 8 & 0.989 & 1.77 & 82.666 & & & & \\
\hline 9 & 0.872 & 1.575 & 84.241 & & & & \\
\hline 10 & 0.74 & 1.355 & 85.596 & & & & \\
\hline 11 & 0.711 & 1.307 & 86.903 & & & & \\
\hline 12 & 0.635 & $\frac{1.18}{1.180}$ & 88.083 & & & & \\
\hline 13 & 0.593 & 1.109 & 89.192 & & & & \\
\hline 14 & 0.546 & 1.031 & 90.223 & & & & \\
\hline 15 & 0.524 & 0.994 & 91.217 & & & & \\
\hline 16 & 0.416 & 0.815 & 92.032 & & & & \\
\hline 17 & 0.404 & 0.794 & 92.826 & & & & \\
\hline 18 & 0.375 & 0.746 & 93.572 & & & & \\
\hline 19 & 0.328 & 0.668 & 94.24 & & & & \\
\hline 20 & 0.29 & 0.605 & 94.845 & & & & \\
\hline 21 & 0.28 & 0.587 & 95.432 & & & & \\
\hline 22 & 0.253 & 0.543 & 95.975 & & & & \\
\hline 23 & 0.231 & 0.505 & 96.48 & & & & \\
\hline 24 & 0.194 & 0.444 & 96.924 & & & & \\
\hline 25 & 0.185 & 0.43 & 97.354 & & & & \\
\hline 26 & 0.161 & 0.39 & 97.744 & & & & \\
\hline 27 & 0.135 & 0.347 & 98.091 & & & & \\
\hline 28 & 0.116 & 0.315 & 98.406 & & & & \\
\hline 29 & 0.113 & 0.266 & 98.672 & & & & \\
\hline 30 & 0.108 & 0.242 & 98.914 & & & & \\
\hline 31 & 0.1 & 0.212 & 99.126 & & & & \\
\hline 32 & 0.085 & 0.169 & $\begin{array}{l}99.295 \\
09020\end{array}$ & & & & \\
\hline 33 & 0.074 & 0.134 & 99.429 & & & & \\
\hline $\begin{array}{l}34 \\
35\end{array}$ & 0.065 & 0.093 & 99.522 & & & & \\
\hline $\begin{array}{l}35 \\
36\end{array}$ & 0.06 & 0.087 & 99.609 & & & & \\
\hline $\begin{array}{l}36 \\
37\end{array}$ & $\frac{0.042}{0.0415}$ & $\frac{0.042}{0.042}$ & $\frac{99.651}{99.693}$ & & & & \\
\hline 38 & 0.04 & 0.041 & 99.734 & & & & \\
\hline 39 & 0.038 & 0.04 & 99.774 & & & & \\
\hline 40 & 0.021 & 0.026 & 99.8 & & & & \\
\hline 41 & 0.02 & 0.019 & 99.819 & & & & \\
\hline 42 & 0.019 & 0.018 & 99.837 & & & & \\
\hline $\begin{array}{ll}43 \\
\end{array}$ & 0.018 & 0.017 & 99.854 & & & & \\
\hline 44 & 0.017 & 0.016 & 99.87 & & & & \\
\hline 45 & 0.016 & 0.015 & 99.885 & & & & \\
\hline 46 & 0.015 & 0.014 & 99.899 & & & & \\
\hline 47 & 0.014 & 0.013 & 99.912 & & & & \\
\hline 48 & 0.013 & 0.012 & 99.924 & & & & \\
\hline 49 & 0.012 & 0.011 & 99.935 & & & & \\
\hline 50 & 0.011 & 0.01 & 99.945 & & & & \\
\hline 51 & 0.01 & 0.01 & 99.95 & & & & \\
\hline 52 & 0.009 & 0.009 & 99.964 & & & & \\
\hline 53 & 0.008 & 0.008 & 99.972 & & & & \\
\hline 54 & 0.007 & 0.007 & 99.979 & & & & \\
\hline 55 & 0.006 & 0.006 & 99.985 & & & & \\
\hline 56 & 0.005 & 0.005 & 99.99 & & & & \\
\hline 57 & 0.004 & 0.004 & 99.994 & & & & \\
\hline 58 & 0.003 & 0.003 & 99.997 & & & & \\
\hline 59 & 0.002 & 0.002 & 99.999 & & & & \\
\hline 60 & 0.001 & 0.001 & 100 & & & & \\
\hline
\end{tabular}

The results of the application of the analysis are indicative of the fact that a total of the seven factors that meet the criterion were extracted. These seven factors account for about $81 \%$ of the total variation. The extraction of these seven questions enabled a valid questionnaire.

Given the fact that, based upon the obtained matrix of the unrotated components, it was impossible to group the questions precisely into a particular factor, the validation further continued by applying the Promax rotation (with Kaiser normalization). ${ }^{1}$ This rotation orthogonally rotates unrotated solutions so as to enable correlations between the factors. The results of this rotation are presented in Table 2 .

Table 2 The matrix of the structure

\begin{tabular}{|c|c|c|c|c|c|c|c|}
\hline & \multicolumn{7}{|c|}{ Components } \\
\hline & 1 & 2 & 3 & 4 & 5 & 6 & 7 \\
\hline Q1 & -0.001 & 0.025 & 0.228 & 0.074 & 0.044 & -0.291 & -0.005 \\
\hline Q2 & 0.002 & 0.046 & 0.201 & -0.035 & 0.212 & -0.071 & 0.014 \\
\hline Q3 & 0.071 & -0.116 & 0.25 & 0.093 & 0.02 & -0.045 & -0.075 \\
\hline Q4 & -0.302 & 0.249 & 0.317 & 0.059 & 0.172 & -0.077 & 0.04 \\
\hline Q5 & -0.333 & 0.282 & 0.239 & -0.013 & 0.185 & -0.041 & -0.141 \\
\hline Q6 & -0.275 & 0.101 & 0.269 & 0.097 & 0.165 & -0.156 & -0.32 \\
\hline Q7 & -0.353 & 0.23 & 0.165 & 0.076 & 0.055 & -0.243 & -0.099 \\
\hline Q8 & -0.023 & 0.213 & -0.005 & 0.025 & 0.07 & -0.207 & -0.05 \\
\hline Q9 & 0.027 & 0.334 & 0.026 & -0.198 & -0.022 & -0.243 & -0.213 \\
\hline Q10 & -0.001 & 0.27 & 0.043 & -0.179 & 0.178 & -0.334 & 0.02 \\
\hline Q11 & 0.012 & 0.341 & -0.32 & -0.028 & -0.23 & -0.173 & -0.275 \\
\hline Q12 & 0.062 & 0.334 & -0.302 & $\begin{array}{l}-0.036 \\
\end{array}$ & -0.297 & -0.217 & -0.256 \\
\hline Q13 & -0.035 & 0.185 & -0.169 & 0.015 & -0.084 & -0.054 & -0.559 \\
\hline Q14 & -0.091 & 0.339 & -0.343 & -0.026 & -0.359 & -0.268 & -0.449 \\
\hline Q15 & 0.158 & 0.187 & -0.018 & -0.32 & -0.118 & -0.151 & -0.432 \\
\hline Q16 & -0.143 & 0.325 & 0.069 & -0.208 & -0.1 & -0.037 & -0.548 \\
\hline Q17 & 0.092 & 0.013 & -0.311 & -0.253 & -0.024 & -0.464 & -0.029 \\
\hline Q18 & -0.027 & 0.155 & -0.128 & -0.343 & -0.092 & -0.459 & -0.205 \\
\hline Q19 & 0.321 & 0.021 & 0.102 & -0.441 & -0.265 & -0.254 & 0.001 \\
\hline Q20 & 0.144 & 0.095 & 0.026 & $\begin{array}{l}-0.354 \\
\end{array}$ & -0.201 & -0.364 & 0.125 \\
\hline Q21 & 0.299 & 0.127 & -0.024 & -0.441 & -0.274 & -0.432 & 0.066 \\
\hline Q22 & 0.281 & 0.07 & 0.027 & -0.418 & -0.225 & -0.39 & 0.089 \\
\hline Q23 & 0.002 & 0.243 & 0.057 & -0.032 & -0.501 & -0.035 & 0.01 \\
\hline Q24 & 0.26 & 0.018 & -0.02 & -0.135 & -0.607 & -0.168 & -0.002 \\
\hline Q25 & 0.377 & -0.059 & -0.059 & -0.195 & -0.359 & -0.145 & -0.071 \\
\hline Q26 & 0.257 & 0.014 & -0.039 & -0.253 & -0.344 & -0.031 & -0.214 \\
\hline Q27 & -0.174 & 0.195 & 0.014 & -0.086 & -0.271 & 0.287 & -0.282 \\
\hline Q28 & 0.307 & -0.008 & 0.008 & $\begin{array}{l}-0.345 \\
\end{array}$ & -0.291 & 0.016 & -0.258 \\
\hline Q29 & 0.266 & 0.031 & 0.085 & -0.42 & -0.092 & 0.209 & -0.13 \\
\hline Q30 & 0.241 & 0.008 & 0.025 & -0.414 & -0.095 & 0.217 & -0.153 \\
\hline Q31 & 0.244 & -0.013 & -0.168 & $\begin{array}{l}-0.406 \\
\end{array}$ & -0.002 & 0.15 & -0.1 \\
\hline Q32 & 0.274 & -0.273 & -0.037 & -0.42 & 0.088 & 0.289 & -0.023 \\
\hline Q33 & 0.222 & -0.242 & -0.11 & -0.325 & 0.026 & 0.237 & 0.008 \\
\hline Q34 & 0.248 & -0.224 & -0.095 & -0.2 & 0.058 & 0.096 & -0.167 \\
\hline Q35 & 0.372 & -0.222 & -0.166 & -0.233 & 0.01 & 0.03 & -0.298 \\
\hline Q36 & 0.323 & -0.211 & 0.137 & -0.029 & 0.026 & -0.094 & -0.061 \\
\hline Q37 & 0.218 & -0.221 & -0.023 & 0.248 & -0.259 & 0.014 & -0.2 \\
\hline Q38 & 0.425 & -0.321 & 0.057 & 0.081 & -0.134 & -0.241 & -0.193 \\
\hline Q39 & 0.457 & -0.316 & 0.015 & 0.12 & -0.1 & -0.135 & -0.12 \\
\hline Q40 & 0.374 & -0.366 & -0.072 & 0.256 & -0.105 & -0.152 & -0.223 \\
\hline Q41 & 0.431 & -0.358 & 0.008 & 0.166 & 0.008 & -0.264 & -0.24 \\
\hline Q42 & 0.366 & -0.372 & -0.093 & 0.195 & -0.084 & -0.257 & -0.196 \\
\hline Q43 & 0.379 & -0.354 & -0.045 & 0.136 & 0.033 & -0.304 & -0.266 \\
\hline Q44 & 0.213 & -0.231 & -0.236 & 0.048 & -0.245 & -0.142 & 0.076 \\
\hline Q45 & 0.399 & -0.21 & -0.23 & 0.064 & -0.138 & -0.111 & -0.115 \\
\hline Q46 & 0.312 & -0.225 & -0.178 & 0.017 & -0.101 & -0.168 & -0.035 \\
\hline Q47 & -0.248 & 0.218 & -0.273 & -0.041 & -0.085 & 0.002 & 0.012 \\
\hline Q48 & 0.167 & -0.254 & -0.189 & -0.02 & -0.014 & -0.193 & -0.045 \\
\hline Q49 & 0.204 & 0.05 & -0.584 & -0.163 & 0.159 & -0.128 & 0.088 \\
\hline Q50 & 0.128 & 0.034 & -0.629 & $\begin{array}{l}-0.164 \\
\end{array}$ & 0.296 & -0.168 & -0.081 \\
\hline Q51 & 0.071 & 0.096 & -0.665 & $\begin{array}{l}-0.215 \\
\end{array}$ & 0.283 & -0.145 & -0.182 \\
\hline Q52 & 0.15 & 0.034 & -0.657 & -0.091 & 0.03 & -0.133 & -0.143 \\
\hline Q53 & 0.087 & 0.171 & -0.317 & 0.18 & -0.131 & 0.037 & -0.373 \\
\hline Q54 & -0.028 & 0.078 & -0.46 & -0.089 & 0.047 & -0.085 & -0.046 \\
\hline Q55 & 0.091 & 0.182 & -0.479 & 0.077 & -0.206 & -0.005 & -0.127 \\
\hline Q56 & 0.081 & -0.007 & -0.269 & 0.236 & -0.404 & -0.019 & 0 \\
\hline Q57 & -0.055 & 0.2 & -0.275 & 0.16 & -0.296 & 0.035 & 0.102 \\
\hline Q58 & -0.234 & 0.322 & -0.095 & 0.202 & -0.248 & -0.009 & 0.2 \\
\hline Q59 & -0.034 & 0.137 & -0.214 & $\begin{array}{l}-0.017 \\
\end{array}$ & -0.043 & 0.044 & 0.33 \\
\hline Q60 & -0.231 & 0.079 & -0.175 & 0.207 & -0.2 & 0.117 & 0.198 \\
\hline
\end{tabular}

Source: the authors' calculations

Due to the length of the paper, the matrices of the unrotated and rotated components are not presented herein. 
Based on this rotation, a total of the seven key factors that were reformulated into the seven questions included in a new questionnaire were identified. More precisely, the new questionnaire consisted of seven questions. Each question is specially discussed in each individual item given further in the paper.

The questionnaire consisted of seven questions. Each question is separately processed in every individual point that follows in our further presentations.

In the first part of the Questionnaire, the respondents' sociodemographic characteristics (i.e. their sex, age, employment status (employed, unemployed, students or retired persons), their marital status (married, cohabiting or single), the number of household members, and the number of years of education) were determined.

The second part of the Questionnaire was dedicated to certain aspects of behavior when buying wine: the usual frequency of buying wine at a monthly level (more rarely than once a month, once a month, several times a month, once a week, several times a week, on a daily basis) and the brands in the assortment of a retail shop where the largest number of wine purchases were made. At the same time, what a shop looked like, what it was specialized in (whether it was a shop only selling wine or a general retail store - a supermarket, a 24-hour service shop, etc.) was in focus.

The third part of the Questionnaire related to the statement of the favorite brand/wine that is used in the household the most. Apart from that, the respondents were also asked to mention the brand within that sort of wine they prefer the most, even when, first of all, they prefer the sort, not the brand of the wine.

\subsection{Questionnaire}

In order to find out the frequency of buying wine at a monthly level, the consumers were asked a few questions. The first question was about the usual purchases at a monthly level. As can be concluded from Table 3, more than a half of the respondents buy wine at least once a month.

Table 3 The usual purchase of wine at a monthly level

\begin{tabular}{l|c|c}
\hline $\begin{array}{l}\text { Respondents' } \\
\text { answers }\end{array}$ & $\begin{array}{c}\text { Number of } \\
\text { survey answers }\end{array}$ & Share in \% \\
\hline $\begin{array}{l}\text { More rarely than once } \\
\text { a month }\end{array}$ & 57 & 24.78 \\
\hline Once a month & 71 & 30.87 \\
\hline Several times a month & 42 & 18.26 \\
\hline
\end{tabular}

\begin{tabular}{l|c|c}
\hline Once a week & 27 & 11.74 \\
\hline Several times a week & 24 & 10.43 \\
\hline Daily & 9 & 3.91 \\
\hline Total $\mathrm{n}=230$ & 230 & 100.0 \\
\hline \multicolumn{2}{r}{ Source: the authors' survey-based calculation }
\end{tabular}

There is also a substantial number of consumers buying wine several times a month, as well as those buying it several times a week. That indicates the fact that consumers buy and consume wine eagerly.

The next question posed to the respondents related to their selection of the shop where they made the largest number of wine purchases.

Table 4 In what shop do you buy wine most frequently?

\begin{tabular}{l|c|c}
\hline $\begin{array}{l}\text { Respondents' } \\
\text { answers }\end{array}$ & $\begin{array}{c}\text { Number of survey } \\
\text { answers }\end{array}$ & Share in \% \\
\hline $\begin{array}{l}\text { At a } \\
\text { specialized } \\
\text { wine shop }\end{array}$ & 4 & 1.74 \\
\hline $\begin{array}{l}\text { At shops of } \\
\text { supermarket } \\
\text { chains }\end{array}$ & 121 & 52.61 \\
\hline $\begin{array}{l}\text { At a self- } \\
\text { service shop }\end{array}$ & 84 & 36.52 \\
\hline $\begin{array}{l}\text { At a 24-hour } \\
\text { service shop }\end{array}$ & 18 & 7.83 \\
\hline $\begin{array}{l}\text { In another } \\
\text { place }\end{array}$ & 3 & 1.30 \\
\hline Total n=230 & 230 & 100.0 \\
\hline \multicolumn{2}{|c|}{ Source: the authors' survey-based calculation }
\end{tabular}

The answers given to this question are interesting. More than $52.61 \%$ of the respondents buy wine at shops of big supermarket chains (Tempo, Maxi, Aman, Idea, Roda, Lidl). Selfservice shops and 24-hour service shops owned by small merchants rank second and third. The number of only four respondents, i.e. $1.74 \%$, who buy wine at a specialized wineshop is almost negligible. The reason for such a small purchase of wine should be sought in the simple reason that there are a very small number of shops like these on the territory of Niš. Based on the answers like these, it is possible to conclude that the respondents buy wine at the shops of famous supermarket chains to the greatest extent.

As has already been said, the third part of the Questionnaire related to the statement of the favorite brand/wine which is consumed the most in the household. At the same time, the following sorts of wine were in our focus: white and red wines, rosé and champaign (sparkling wines). According to the answers given by the respondents, it can be seen that red wines are consumed the most. On the other hand, the 
second-ranked is white wine, which does not lag much behind red wine.

Table 5 Which favorite sorts of wine are consumed in your household?

\begin{tabular}{l|c|c}
\hline $\begin{array}{l}\text { Respondents' } \\
\text { answers }\end{array}$ & $\begin{array}{c}\text { Number of } \\
\text { survey } \\
\text { answers }\end{array}$ & Share in \% \\
\hline White wine & 83 & 36.09 \\
\hline Red wine & 95 & 41.30 \\
\hline Rosé & 36 & 15.65 \\
\hline Champaign & 16 & 6.96 \\
\hline Total n=230 & 230 & 100.0 \\
\hline \multicolumn{2}{r}{ Source: the authors' survey-based calculation }
\end{tabular}

The respondents were also asked the question: which sorts of wine within white wine are most gladly consumed.

Table 6 Which favorite sorts of white wine are consumed in your household?

\begin{tabular}{l|c|c}
\hline $\begin{array}{l}\text { Respondents' } \\
\text { answers }\end{array}$ & $\begin{array}{c}\text { Number of } \\
\text { survey answers }\end{array}$ & Share in \% \\
\hline Pinot Blanc & 36 & 15.65 \\
\hline Riesling & 39 & 16.96 \\
\hline Chardonnay & 18 & 7.83 \\
\hline I do not know & 137 & 59.57 \\
\hline Total n=230 & 230 & 100.0 \\
\hline \multicolumn{3}{c}{ Source: the authors' survey-based calculation }
\end{tabular}

Based on the received answers, it can be concluded that the respondents most frequently buy and simultaneously consume Riesling white wine $(16.96 \%)$. That same question was also asked about buying and consuming red wine.

Table 7 Which favorite sorts of red wine are consumed in your household?

\begin{tabular}{l|c|c}
\hline $\begin{array}{l}\text { Respondents' } \\
\text { answers }\end{array}$ & $\begin{array}{c}\text { Number of } \\
\text { survey answers }\end{array}$ & Share in \% \\
\hline $\begin{array}{l}\text { Cabernet } \\
\text { Sauvignon }\end{array}$ & 38 & 16.52 \\
\hline Merlot & 23 & 10.00 \\
\hline Pinot Noir & 12 & 5.22 \\
\hline I do not know & 158 & 68.78 \\
\hline Total n=230 & 230 & 100.0 \\
\hline \multicolumn{2}{l}{ Source: the authors' survey-based calculation }
\end{tabular}

When the answers related to the asked question about the sorts of red wine most gladly bought/consumed are concerned, the respondents answered that the wine Cabernet Sauvignon was consumed the most.

Besides, the respondents were also asked to state the brand within the sort of wine they prefer the most, even when the sort of that wine, not a wine brand, is their favorite. It was impossible to obtain a simple answer to this question because of a large number of the brands of the wines present in our market. In order to relatively narrow the answer to this question, the consumers were, first of all, asked to mention the domestic wine brands they like to drink the most. In compliance with the posed question, the respondents answered as shown in Table 8.

Table 8 Which are your favorite domestic wine brands consumed in your household?

\begin{tabular}{l|c|c}
\hline $\begin{array}{l}\text { Respondents' } \\
\text { answers }\end{array}$ & $\begin{array}{c}\text { Number of } \\
\text { survey answers }\end{array}$ & Share in \% \\
\hline $\begin{array}{l}\text { Ždrepčeva krv } \\
\text { (Stallion's } \\
\text { Blood) }\end{array}$ & 24 & 10.43 \\
\hline $\begin{array}{l}\text { Medveđa krv } \\
\text { (Bear's Blood) }\end{array}$ & 17 & 7.39 \\
\hline $\begin{array}{l}\text { Tri Morave } \\
\text { (Three }\end{array}$ & 8 & 3.48 \\
Moravas) & 181 & 78.70 \\
\hline I do not know & 230 & 100.0 \\
\hline Total n=230 & Source: the authors' survey-based calculation
\end{tabular}

What can immediately be noticed when speaking about the posed question is that wine buyers and consumers know best the wines mainly present on the market. At the same time, those wines are also bought most frequently. These wines are also reasonably priced.

Table 9 Do you buy domestic or foreign wines?

\begin{tabular}{l|c|c}
\hline $\begin{array}{l}\text { Respondents' } \\
\text { answers }\end{array}$ & $\begin{array}{c}\text { Number of } \\
\text { survey answers }\end{array}$ & Share in \% \\
\hline Domestic wines & 67 & 29.13 \\
\hline Foreign wines & 56 & 24.35 \\
\hline I do not know & 107 & 46.52 \\
\hline Total $n=230$ & 230 & 100.0 \\
\hline
\end{tabular}

Source: the authors' survey-based calculation

The respondents were also asked a question related to the purchase of domestic/purchase of foreign wines ratio. We were interested in finding out which wines were more popular with our consumers. According to the answers obtained, it can be noticed that domestic wines are but slightly more popular than foreign wines. A large number of the respondents did not know how to answer this question, either.

\section{Conclusion}

In spite of certain limitations related to buying and consuming wine, which is the subject matter of our research study, it can be highlighted that there is a certain theoretical contribution out of which it may be possible to make a framework for understanding the behavior of wine consumers. We consider that our research studies can help to some extent to perceive the consumer behaviors that may help wineries to ensure their survival and growth on the unstable and competitive wine 
market. First, it was noticed in our research study that it was very significant whether wine consumers were or were not knowledgeable of the wines they drank. The knowledge of wine significantly influences consumer behavior when buying and consuming wine in general.

We consider that wineries should help consumers create new types of knowledge and impressions when buying and consuming wines. The majority of wine consumers are either confused or insufficiently educated about wines. Consumers feel frightened because of a large number of the wines offered on the market, and they have a problem to remember which wines they have bought and which wines they have liked. The researchers who observe consumer behavior have noticed that buyers are confused during the wine selection process. When buying, they feel insecure and have a problem which wine to choose (Stallcup, 2005). It is our wish to highlight the fact that the problem related to a choice of wine appears at a global level, not only in our country. The world wine market is big and quite diverse.

Finally, we want to highlight the fact that winegrowing production still has a modest annual share in the total achieved value of agricultural production, only accounting for a few percentages. Recently, the deficit in foreign-trade exchange has been explained by the growing trend of the domestic consumption of wine. It is a good trend, which can certainly encourage wine producers.sm

\section{Acknowledgement}

As a research study, the paper is funded by the Ministry of Education, Science and Technological Development of the Republic of Serbia

\section{References}

Balenović, I., Ignjatijević, S., Stojanović, G., Vapa Tankosić, J., Lekić, N., Milutinović, O., Gajić, A., Ivaniš, M., Bošković, J., Prodanović, R., Puvača, N., \& Duđak, L. (2021). Factors Influencing Wine Purchasing by Generation $\mathrm{Y}$ and Older Cohorts on the Serbian Wine Market. Agriculture, 11(11), 1054.

https://doi.org/10.3390/agriculture11111054
Cristófol, F. J., Cruz-Ruiz, E., \& Zamarreño-Aramendia, G. (2021). Transmission of Place Branding Values through Experiential Events: Wine BC Case Study.

Sustainability, 13(6), 3002. https://doi.org/10.3390/su13063002

Dressler, M., \& Paunovic, I. (2021). The Value of Consistency: Portfolio Labeling Strategies and Impact on Winery Brand Equity. Sustainability, 13(3), 1400. https://doi.org/10.3390/su13031400

Fahy, J. \& Jobber, D. (2012). Foundations of Marketing. McGraw-Hill Europe: Madrid.

Field, A. (2009). Discovering Statistics using SPSS. Sage: London.

Hinkin, T.R. (1998). A brief tutorial on the development of measures for use in survey questionnaires. Organizational Research Methods, 1 (1), 104-121. https://doi.org/10.1177/109442819800100106

Kotler, P., \& Armstrong, G. (2014). Principles of Marketing. Upper Saddle River: N.J., Pearson.

Kotler, P., \& Keller, K. L. (2006). Marketing Management: Pearson International Edition. Pearson Prentice Hall.

Merlino, V. M., Fracassetti, D., Di Canito, A., Pizzi, S., Borra, D., Giuggioli, N. R., \& Vigentini, I. (2021). Is the Consumer Ready for Innovative Fruit Wines? Perception and Acceptability of Young Consumers. Foods, 10(7), 1545. https://doi.org/10.3390/foods 10071545

Martinho, V. J. P. D. (2021). Contributions from Literature for Understanding Wine Marketing. Sustainability, 13(13), 7468. https://doi.org/10.3390/su13137468

Petrović, I., (2013), Mogućnost preimene faktorske analize u sociologiji: primer proučavanja vrednosnih orijentacija. Sociologija, 55(4), $557-588$. https://doi.org/10.2298/SOC1304557P

Salai, S., Gašović, M., \& Čelić, M. (2013). Marketing research into wine consumption determinants in Vojvodina. Marketing, 44(2), 103-114. https://doi.org/10.5937/markt1302103S

Stallcup, J. (2005). Toppling the wall of confusion. Wine Business Monthly, 12(4).

Vlahović, B., Potrebić, V., \& Jeločnik, M. (2013). Correction: Branislav Vlahović, Velibor Potrebić, Marko JeločnikPreferences of wine consumers on Serbian market (59, pg. 37, 2012). Ekonomika poljoprivrede, 60(3), 676-676.

\section{$\triangle$ Correspondence}

\section{Curčić Nikola}

Institute of Agricultural Economics

Volgina 15, 11060, Belgrade, Serbia

E-mail: nikola_c@iep.bg.ac.rs 